\title{
Determinants of Capital Structure: Empirical Evidence from Large Taxpayer Share Companies in Ethiopia
}

\author{
Usman Muhammed Umer ${ }^{1}$ \\ ${ }^{1}$ College of Business and Economics, Mekelle University, Mekelle, Ethiopia \\ Correspondence: Usman Muhammed, College of Business and Economics, Mekelle University, Mekelle, Ethiopia. \\ E-mail: usmuh@yahoo.com
}

Received: October 21, 2013

Accepted: October 28, $2013 \quad$ Online Published: December 23, 2013

doi:10.5539/ijef.v6n1p53

URL: http://dx.doi.org/10.5539/ijef.v6n1p53

\begin{abstract}
The purpose of this study is to identify the determinants of capital structure of large taxpayer share companies in Ethiopia. In this paper, econometric analysis were performed for a panel of 37 listed companies in Ethiopian Revenue and Customs Authority (ERCA) large taxpayers' branch office in Addis Ababa for the study period of 2006-2010. Nine conventional explanatory variables were adopted in this study, including profitability, size, age, tangibility, liquidity, non-debt tax shield, growth, dividend payout ratio and earnings volatility. As a result of the improvement in the existing estimation methods that enables to employ cross-sectional and time-series data concurrently, random-effect panel data regression was applied to study the effect of selected independent variables on capital structure. The result shows that size, age, tangibility, liquidity position and non-debt tax shield of a company are positively correlated with leverage, whereas profitability, earnings volatility and dividend payout ratio are negatively associated with leverage. Growth variable was found to be statistically insignificant in affecting leverage of large taxpayer share companies in Ethiopia. The sign of these relations suggest that, Agency cost theory provide more convincing evidence than other capital structure theories in elucidating the capital structure of large taxpayer share companies in Ethiopia.
\end{abstract}

Keywords: capital structure, panel data, capital structure theories, large taxpayer share companies, Ethiopia

\section{Introduction}

Any kind of business activity depends on finance to meet its fixed assets and working capital requirements, and finance is accelerating engine of business activities. Whether the businesses are big or small, they need fund to fulfill their business activities. Accordingly, the capital structure decision of a company is at the heart of other decisions in the area of corporate finance. Theoretical discourses on capital structure of the firm initiate from the irrelevance proposition of Modigliani and Miller (1958). It was based on a number of unrealistic inferences. In 1963 Modigliani and Miller introduced the effect of taxes into the original model. This led to the advent of the trade-off capital structure theory, where the tax-related advantages of debt such as interest tax-shield were offset by the agency costs arising between shareholders and creditors. Another theory based on asymmetric information between 'outside' investors and 'inside' managers, the Pecking order theory (Myers, 1984; Myers \& Majluf, 1984) was commenced. This theory proposes that when internal finance are not enough for investment purpose, the firms prefer to raise capital from external sources in debt markets, and finally with equity finance only as a last resort. A further approach initiated by Jansen and Mecling (1976) considered potential agency costs of the firms as a result of a nexus of principal-agent relationships. This theory is known as Agency Cost theory.

After Modigliani and Miller proposition in 1958, various researchers have attempted to pinpoint what determines the firm's capital structure and the recognition of factors has been a subject of debate for the past five decades. However, most of these capital structure studies provide empirical evidence concerning whether the theoretical models have explanatory power when applied to the real business world. Majority of them are based on data collected from developed and emerging economies, which have many institutional similarities (Rajan \& Zingales, 1995; Wald, 1999; Wiwattanakantang, 1999; Um, 2001; Ozkan, 2001; Bevan \& Danbolt, 2002; Philippe et al., 2003; Bancel \& Mitto, 2004; Fakher, Kenbata, \& Lynn, 2005; Huang \& Song, 2006), but little work has been done to advance our knowledge on capital structure within developing countries (Booth et al., 2001; Myroshnichenko, 2004; Rafiu \& Akinlolu, 2008) that have different institutional structure. And as argued by most researchers findings from theoretical and empirical study carried out in developed countries do not provide 
sound evidence for developing countries too. Therefore, the overall objective of this research is to investigate the dynamics involved in the determinants of capital structure of large taxpayer share companies in Ethiopia and provide a significant contribution to the understanding of the determinants behind the capital structure pertaining to developing countries.

This paper is structured as follows. Section 2 provides theoretical and empirical backgrounds on determinants of capital structure. Section 3 and 4 describes data collection methods and econometrics model employed in this study respectively. Empirical results and discussions are presented in section 5. Finally, the conclusions based on the finding of this study are summarized in section 6 .

\section{Determinants of Capital Structure}

This section critically reviews nine explanatory variables that have been derived from both theoretical and empirical studies in order to examine determinants of capital structure. These variables are denoted as: profitability, size, tangibility, non-debt tax shield, growth, age, liquidity, dividend payout ratio and earnings volatility. The explained variable in these studies are leverage.

\subsection{Profitability}

Most capital structure studies consider the profitability of a firm as one of key factors that affects capital structure choice. However, the sign of relationship between profitability and leverage of a firm are inconsistent. Trade-off theory argues that more profitable companies ought to have higher debt ratio since they require to shield there income from taxes. Conversely, the pecking order theory (Myers, 1984) postulates that ceteris paribus more profitable firms are, the more internal financing they have, the firms give priority to internal financing to external one. Therefore, the more firms are profitable, the lower they need for external financing and then they have lower leverage.

When we see most empirical studies on capital structure they reveal a negative correlation between profitability and leverage of a firm, which is consistent with the pecking order theory, for example the work of Titman and Wessels (1988); Rajan and Zingales (1995); Bevan and Danbolt (2002); Antoniou, Guney and Paudyal (2002) from developed countries and the study of Wiwattanakantang (1999); Pandy (2001); Booth et al. (2001); Al-Sakran (2001); Chen (2004) from developing countries find a negative relationship between profitability and leverage.

\subsection{Size}

Even though, several studies discover that the size of a firm is a good determinant of leverage ratio, there are contradictory views about the correlation of size and leverage of a firm. Titman and Wessel (1988) suggest that larger firms being more diversified and have lesser chances of bankruptcy, this enables them to finance with debt at more favorable interest rate (Ferri \& Jones, 1979). In addition to this, many research findings show that the size of a firm positively influences the leverage ratio. Wiwattanakantang (1999); Booth et al. (2001); Al-Sakran (2001); Pandy (2001); Huang and Song (2002) discover a significant positive association between size and leverage ratio in developing countries. Whereas, Rajan and Zingales (1995) suggests that as a result of less asymmetric information about the larger companies, it diminishes the chance of undervaluation of the new equity issue. This makes current shareholders willing to embark up on issuing stock as a way of getting finance rather than granting loan. This implies that there is negative relation between size and leverage of firms.

\subsection{Tangibility}

Tangible assets are the most widely accepted source for the bank borrowing and secured debts, since it can serve as collateral, which diminish the risk of the lender. That means the asset structure of a firm plays a significant role in determining the firm's capital structure. It is important to mention here the investigation of Titman and Wessels (1988) and Rajan and Zingales (1995) in developed countries; Wiwattanakantang (1999) in Thailand; Um (2001) in South Korea; Attaullah and Sufiullah (2007) in Pakistan and the study of Dilek, Ozlem and Ayca (2009) from Turkish firms reveals a positive relationship between tangibility and leverage of a firm. Moreover, Scott (1977); Myers (1977); Myers and Majiluf (1984) and Williamson (1988) suggests similar conclusion.

Other researches such as Booth et al. (2001) in ten developing countries and Huang and Song (2002) in China found that companies with more tangible assets tend to use less debt ratio and they suggested the existence of negative association between leverage and tangibility of assets. Likewise, Myroshnichenko (2004) also observes negative correlation between tangibility of assets and short-term corporate leverage for Ukrainian firms. But, most empirical studies disclose the existence of positive relationship between leverage and tangibility of asset. 


\subsection{Non-Debt Tax Shield}

One item besides interest which contributes to reduce tax payments are labeled as non-debt tax shields (for instance depreciation). DeAngelo and Masulis (1980) argued that non-debt tax shields can replace of tax advantage of debt financing and a firm with large non-debt tax shields is more likely to use smaller amount of debt. For this reason, the relationship between non-debt tax shields and leverage is supposed to be negative. Inverse relation between non-debt tax shields and leverage is also found by Kumer and Reddy (1998); Huang and Song (2002); and Titman and Wessel (1988). Even though, other researchers such as Rafiu and Akinlolu (2008) and Bradly et al. (1984) identify a positive correlation between leverage ratio and non-debt tax shields.

\subsection{Growth}

Pecking order theory argues that growing firms which use first internal sources of finance may not be sufficient for investment purpose and the next option is to use debt financing. This implies that a growing firm will have a high level of leverage. However, the trade-off theory suggests that in order to avoid asset substitution and under-investment that can arise from stockholder-bondholder agency conflicts, firms with more investment opportunities have less leverage. This theory estimates a negative relationship between a firm with growth opportunities and the corresponding leverage.

Empirical evidences concerning the relationship between growth and leverage are much notorious. Titman and Wessel, (1988) and Attaullah and Sufiullah (2007) mentions that the agency costs of growing firms are likely to be higher and this results high cost of debt. Thus, growing firms facing high cost of debt will use less debt and more equity. Consequently, a negative relationship between growth and financial leverage is expected. In line with this prediction, Jensen and Meckling (1976), Myers (1984), Stulz (1990), Chung (1993), and Rajan and Zingales (1995) put forward a negative correlation between growth and the level of leverage from developed countries. However, Kester (1986) and Huang and Song (2002) demonstrate a positive relation between growth and leverage.

\section{$2.6 \mathrm{Age}$}

There are controversies between trade-off and pecking order theories on the effect of age on leverage. The trade-off theory suggested that as the firm become mature, its borrowing capacity increases implying a positive relation between leverage and age of the firm. Additionally, Berger and Udell (1998) states that as the firm matures it could have increased fixed assets in the form of land and building on which it may secure mortgage finance an long-term debt and also may accumulated assets uses as debt collateral in the form of inventory, account receivable and equipment. However, pecking order theory argued that as the firm matures, it builds its reputation. Which means the good name a firm built up over the years; the name is recognized by the market, thus leading to better and easier to raise equity finance than debt capital.

A study by Petersen and Rajan (1994) reveals that mature firms have higher debt ratio since they are supposed of high quality firms. Furthermore, Hall, Hutchinson and Michaelas (2004) agreed that age is positively related to long-term debt but negatively related to short-term debt. Nevertheless, Esperanca, Gama and Gulamhussen (2003) found that age is negatively related to both long-term and short-term debt.

\subsection{Liquidity}

The relationship between leverage and liquidity position of a firm is also a debatable issue. Bogdana (2009) argued that firms with higher liquidity are able to have higher debt to equity ratio by the intuition that they are able to meet short-term obligations. Thus, positive relationship expected between liquidity and leverage. The observation of Williamson (1988), Shleifer and Vishny (1992), Maksimovic and Phillips (2001) and Valeriy (2007) regarding the relationship between asset liquidity and leverage reveals similar conclusion. Moreover, other studies that examines the relationship between leverage and asset liquidity such as Morellec (2001), find evidence that liquidity is positively related to debt to equity ratio.

On the other hand, firms with higher liquidity assets may also use these assets to finance their activity by themselves and not to use debt financing. This will exercise negative relationship between liquidity and leverage ratio. The finding of Ozkan (2003) study supports this premise in the UK.

\subsection{Dividend Payout Ratio}

Dividend is the amount of net income that is paid out to shareholders. The bankruptcy theory maintains inverse relation between firm dividend payout ratio and leverage. According to this theory, the low dividend payout ratio demonstrates increase in the equity base for debt capital and a low probability of bankruptcy. Thus, the low bankruptcy cost implies the high level of leverage in the capital structure. The finding of Keshar (2004) is also in 
support of the bankruptcy cost theory. Conversely, pecking order theory proposes a positive relation between debt level in the capital structure and dividend payout ratio. This theory puts hierarchical order the sources of financing of a company. This order begins with internal source of finance to external one. Instead of distributing high dividend, and meeting the financial requirement from debt capital, management retains the earnings. Therefore, the lower dividend payout ratio implies the lower level of debt in capital structure. The findings of Rafiu and Akinlolu (2008) are consistent with pecking order theory.

\subsection{Earning Volatility}

Earning volatility is described as the inherent business risk in the operation of a firm or a result of inefficient management practices. The combined prediction of trade-off theory and pecking order theory suggests a negative relationship between earning volatility and leverage due to the increases in the likelihood of being unable to meet financial obligations with the increase in earnings volatility. Likewise, Bhaduri (2002), Frank and Goyal (2003), Attaullah and Sufiullah (2007), Bradly et al. (1984), and Titman and Wessel (1988) reported negative relationship between earning volatility and leverage. However, Kim and Sorensen (1986) found positive relation between earning volatility and firm's leverage.

\section{Data Collection and Variables}

In this study, the data required for the purpose of analysis were collected from secondary sources: article of association and audited financial statements, basically of balance sheet and Income statement of sample companies for a period of six years (2005-2010). Before the data was collected in an effort to mitigate sample selection bias from working population and reducing the effect of abnormal samples, different levels of sample restriction criteria were imposed on firms in order to be included in the sample. The first criterion to be fulfilled by a firm is the company need to hold the legal status of 'Share Company' from the eight form of business organization i.e. ordinary partnership, limited partnership, general partnership, joint venture, share company, private limited company, sole proprietorship and co-operative, according to the classification of the Commercial Code of Ethiopia (1960). The second level of sampling criteria was that the total study population includes only 'large taxpayer share companies' engaged in different class of economy and listed in Ethiopian Revenues and Customs Authority (ERCA) large taxpayer branch office Addis Ababa. According to ERCA taxonomy, large taxpayers share companies include all bank and insurance companies, and others firms with a minimum annual turnover of Birr 15 million.

Then I made two stage sample restriction criteria to arrive at a definite study population. Firstly, firms belonging to bank, insurance or other financial industries are deliberately excluded from the analysis because of their specific financial behavior and particular nature. Like the study of Francisco (2001), Rajan and Zingales (1995) and Tongying and Junyong (2005). Subsequently, I made the second level of sample restriction that firms with missing financial data for a period covering six years from 2005-2010 are also excluded from the study so as to examine the trend of firms financing decision. The data pertinent to year 2005 is used only to compute the growth variable for the year 2006 of all observation, i.e. percentage change in total asset. After I investigated the financial statement of 76 share companies registered in ERCA large taxpayers' branch office, only 37 firms that satisfy the above criterion were included in the sample study. The sample is distributed over 6 industries based on Standard Industrial Classification (SIC) of Ministry of Trade and Industry in Ethiopian as shown below in Table 1.

Table 1. Standard Industrial Classification (SIC) of companies

\begin{tabular}{cccc}
\hline & Industry & Companies & $\%$ \\
\hline Division 1 & Manufacturing & 21 & 56 \\
Division 2 & Wholesale Trade & 6 & 16.23 \\
Division 3 & Construction & 4 & 10.81 \\
Division 4 & Communication and Other Utility & 3 & 8.1 \\
Division 5 & Business Service & 2 & 5.4 \\
Division 6 & Agriculture and Related Service & 1 & 2.7 \\
Total & & 37 & 100 \\
\hline
\end{tabular}

\subsection{Research Variables and Hypothesis}

In order to analyze the determinants of capital structure the following ten key variables were identified: leverage, profitability, size, tangibility, non-debt tax shield, growth, age, liquidity, dividend payout ratio and earnings 
volatility.

\subsubsection{Dependent Variable}

The dependent variable used in this study is leverage. Leverage can be measured by using different financial ratios. However, as per the definition of capital structure, which is the mix of long-term sources of finance, the leverage variable used in this study measured as the ratio of long-term debt to total assets.

\subsubsection{Independent Variables}

The independent variables include profitability, size, tangibility, non-debt tax shield, growth, age, liquidity, dividend payout ratio and earnings volatility. The whole variable for this study is derived from book values in line with the argument by Myers (1984) that book values are proxies for the value of assets in place.

Consistent with the extant literature and previous empirical studies, the following hypotheses were developed to test the relationship between the level of leverage and the independent variables.

Hypothesis 1: There is significant negative relationship between profitability and leverage of a firm.

This hypothesis is tested using the Profitability (PROF) variable, which is defined as return on assets, the ratio of operating income (EBIT) to total assets.

Hypothesis 2: There is strong positive relationship between size and leverage of a firm.

The size (SIZE) variable of this study measured as the natural logarithm of total asset. Another possibility is to proxy the size of a company by the natural logarithm of sales.

Hypothesis 3: There is significant positive relationship between tangible assets and leverage of a firm.

The tangibility (TANG) of firm asset is obtained using the quotient between fixed asset and total assets.

Hypothesis 4: There is strong negative relationship between non-debts tax shields and leverage ratio.

The ratification of this hypothesis is made using non-debts tax shields (NDTS) variable, which is defined as the ratio between depreciation and total assets.

Hypothesis 5: There is significant negative relationship between growth and leverage of a firm.

As stated by Titman and Wessel (1988) different studies use different techniques to measures of growth variable; like research expenditure to sales measure, market to book value of equity and annual percentage increase in total assets. Due to the fact that, the data taken from the Ethiopian Revenues and Customs Authority (ERCA) does not contain information on annual research expenditure and stock prices, a percentage of increase in total assets of a firm is used to proxy growth (GROW) variable.

Hypothesis 6: There is significant negative relationship between age and leverage of a firm.

The age (AGE) variable is obtained using the number of years a firm stays in the business.

Hypothesis 7: There is significant positive relationship between liquidity and leverage of a firm.

The liquidity (LIQU) variable introduced to test this hypothesis is defined as the ratio between current asset and current liabilities.

Hypothesis 8: There is strong positive relationship between dividend payout Ratio and leverage ratio.

In order to measure this hypothesis the dividend payout ratio (DPR) variable is defined as the quotient between cash dividend and total net income. Similar measurement is also followed by Keshar (2004).

Hypothesis 9: There is strong inverse relationship between Earning volatility and leverage ratio.

This hypothesis is assessed using the earning volatility (EV) variable, defined as one over the square root of the standard deviation of operating income (EBIT).

\section{Econometrics Model: Panel Data Model}

The panel character of the data collected in this study allows using a panel data model. Panel data is a combination of time-series and cross-section data. According to Mohammed, (2007) the panel regression equation varies from a regular time-series or cross-section regression by the double subscript attached to each variable.

The basic framework for panel data estimation is a regression model of the following form:

$$
\mathrm{Y}_{\mathrm{it}}=\alpha+\sum_{K=1}^{9} \beta_{i t k} X_{i t K}+u_{i}+\varepsilon_{i t}
$$


The subscript i represent the cross-sectional dimension and $t$ denoting the time-series dimension. The leftward variable $\mathrm{Y}_{\mathrm{it}}$ denotes the dependent variable, which is the firm's leverage ratio while $\alpha$ represents the intercept, $\beta_{i t k}$ the coefficient and $X_{i t k}$ the independent variables as follows $(\mathrm{k}=1,2,3 \ldots 9)$.

\subsection{Model Specification}

One of the most crucial questions in panel data modeling concerns the choice between fixed and random effect panel data model. To decide which model is most appropriate, many economists and financial analysts use the following criterion. If the individual-specific dependent unobserved effect $\left(u_{i}\right)$ are correlated with one or more of other independent variables, then the appropriate model is the fixed-effect model. If the individual-specific dependent unobserved effect $\left(u_{i}\right)$ are not correlated with one or more of the independent variables, and if they can be viewed as outcome of a random variable, then the correct model is the random-effect model. In this paper to verify the reliability and functionality of the model and to measure the relationship between a dependent variable and one or more independent variables Hausman Specification testing techniques have been devised to test the chosen regression model.

Table 2. Hausman specification test

\begin{tabular}{ccccc}
\hline & \multicolumn{3}{c}{ Coefficients } \\
\cline { 2 - 5 } & $(\mathrm{b})$ & $(\mathrm{B})$ & $\begin{array}{c}(\mathrm{b}-\mathrm{B}) \\
\text { Difference }\end{array}$ & $\begin{array}{c}\text { sqrt(diag(V_b-V_B })) \\
\text { S.E. }\end{array}$ \\
\hline fixed & random & -0.1462 & 0.0558 & 0.0143 \\
SIZE & -0.0904 & 0.0185 & 0.0106 & 0.0049 \\
TANG & 0.0292 & 0.0865 & -0.0044 & 0.0175 \\
NDTS & 0.082 & 1.0837 & -0.3575 & 0.0276 \\
GROW & -0.0313 & & -0.0223 & -0.009 \\
AGE & 0.0124 & 0.0016 & 0.0107 & 0.0042 \\
LIQU & 0.0096 & 0.074 & 0.0021 & 0.0009 \\
DPR & -0.0439 & -0.0602 & 0.0163 & 0.0021 \\
EV & -255.16 & -112.15 & -143.006 & 62.97 \\
\hline
\end{tabular}

Note: $\mathrm{b}=$ consistent under Ho and Ha; obtained from xtreg. $\mathrm{B}=$ inconsistent under Ha, efficient under Ho; obtained from xtreg. Test: Ho: difference in coefficients not systematic. Chi2(4) $=(b-B)^{\prime}\left[\left(V_{-} b-V \_B\right)^{\wedge}(-1)\right](b-B)=0.43$. Prob $>$ chi2 $=0.9797$. V_b-V_B is not positive definite.

As shown above in table 2 Hausman's tests provide empirical evidence of P-value of 97.97\%, which means the random-effect estimators are insignificantly different from fixed-effect estimators. This implies that the null hypothesis is accepted and $u_{i}$ is not correlated with $\mathrm{X}_{\mathrm{i}}$. Therefore, the random-effect model is the appropriate model.

Thus the following random-effect panel data model was used to test the leverage ratio of the firms.

$$
\mathrm{Y}_{\mathrm{it}}=\alpha+\sum_{K=1}^{9} \beta_{i t k} X_{i t K}+u_{i}+\varepsilon_{i t}
$$

To explain the relationship between firm's leverage ratio and the determinants, the following model is devised.

$$
\begin{gathered}
\text { LEV it }=\alpha+\beta 1 \text { PROF }+\beta 2 \text { SIZE }+\beta 3 \text { TANG }+\beta 4 N D T S+ \\
\beta 5 \text { GROW }+\beta 6 A G E+\beta 7 L I Q U+\beta 8 D P R+\beta 9 E V+u_{i}+\varepsilon_{i t}
\end{gathered}
$$

\section{Results and Discussion}

This section presents the empirical results pertaining to determinants of capital structure. The descriptive statistics of the sample firms includes the number of observations; mean distribution, standard deviation, minimum and maximum values of leverage and nine explanatory variables as presented in Table 3 . 
Table 3. Descriptive statistics of study variables

\begin{tabular}{lccccc}
\hline Variable & Observation & Mean & Std. Dev. & Min & Max \\
\hline LEV & 185 & 0.09281 & 0.17260 & 0 & 0.78 \\
PROF & 185 & 0.10290 & 0.19284 & -0.68 & 1.06 \\
SIZE & 185 & 18.2705 & 1.66464 & 11.24 & 24.12 \\
TANG & 185 & 0.31368 & 0.22882 & 0.071 & 0.85 \\
NDTS & 185 & 0.04302 & 0.03840 & 0.001 & 0.199 \\
GROW & 185 & 0.15449 & 0.43502 & -1.33 & 2.49 \\
AGE & 185 & 21.2648 & 18.1515 & 1 & 116 \\
LIQU & 185 & 3.85463 & 4.85529 & 0.117 & 32.5 \\
DPR & 185 & 0.41587 & 0.47152 & 0 & 3 \\
EV & 185 & 0.00056 & 0.00034 & 0.00001 & 0.0016 \\
\hline
\end{tabular}

In the first place, the average leverage proportion in financing the total asset of large taxpayer share companies in Ethiopia is $9.28 \%$. Which means $90.72 \%$ of the total asset invested is left as a buffer being from short-term debt and equity claim. The standard deviation $17.3 \%$ indicates a wide variation in leverage ratio among sample companies. The minimum and the maximum value of leverage ratio are 0 and $78 \%$ respectively.

Before running the regression, inspection of the multicollinearity problem was carried out. According to Lewis-Beck (1993) suggestion in order to find out the multicollinearity problem, the bi-variant correlations among the independent variables should be examined and the existence of correlation of about 0.8 or larger indicates a problem of multicollinearity. The correlation matrix in table 4 below shows that all correlation value is less than 0.8. This implies that there is no multicollinearity problem in the model. However, test for autocorrelation (errors associated with one observation are correlated with the error of any other observation) were not made since panel data analysis technique mitigates the autocorrelation problem.

Table 4. Correlation matrix of variables

\begin{tabular}{|c|c|c|c|c|c|c|c|c|c|c|}
\hline & LEV & PROF & SIZE & TANG & NDTS & GROW & AGE & LIQU & DPR & EV \\
\hline LEV & 1 & & & & & & & & & \\
\hline \multirow[t]{2}{*}{ PROF } & -0.3076 & 1 & & & & & & & & \\
\hline & 0.0000 & & & & & & & & & \\
\hline \multirow[t]{2}{*}{ SIZE } & 0.4129 & -0.2119 & 1 & & & & & & & \\
\hline & 0.0000 & -0.0038 & & & & & & & & \\
\hline \multirow[t]{2}{*}{ TANG } & 0.4693 & -0.2930 & 0.4330 & 1 & & & & & & \\
\hline & 0.0000 & -0.0001 & 0.0000 & & & & & & & \\
\hline \multirow[t]{2}{*}{ NDTS } & 0.4726 & -0.0619 & 0.1445 & 0.3636 & 1 & & & & & \\
\hline & 0.0000 & -0.4024 & -0.0497 & 0.0000 & & & & & & \\
\hline \multirow[t]{2}{*}{ GROW } & -0.0080 & 0.0461 & -0.0164 & -0.0387 & 0.0067 & 1 & & & & \\
\hline & -0.9138 & -0.5329 & -0.8243 & -0.6010 & -0.9277 & & & & & \\
\hline \multirow[t]{2}{*}{ AGE } & 0.3118 & 0.0060 & 0.3850 & 0.1603 & 0.1151 & -0.0316 & 1 & & & \\
\hline & 0.0000 & -0.9346 & 0.0000 & -0.0293 & -0.1188 & -0.6693 & & & & \\
\hline \multirow[t]{2}{*}{ LIQU } & 0.0727 & -0.0362 & -0.0662 & -0.0412 & -0.0846 & -0.0273 & -0.0040 & 1 & & \\
\hline & -0.3253 & -0.6251 & -0.3707 & -0.5779 & -0.2521 & -0.7119 & -0.9566 & & & \\
\hline \multirow[t]{2}{*}{ DPR } & -0.3245 & 0.1107 & -0.1636 & -0.2365 & -0.1108 & 0.0441 & -0.0534 & 0.0843 & 1 & \\
\hline & 0.0000 & -0.1334 & -0.0261 & -0.0012 & -0.1332 & -0.5513 & -0.4706 & -0.2538 & & \\
\hline \multirow[t]{2}{*}{ EV } & -0.3116 & 0.0054 & -0.4607 & -0.2555 & -0.1473 & -0.0522 & -0.2018 & 0.2005 & 0.1342 & 1 \\
\hline & 0.0000 & -0.9418 & 0.0000 & -0.0004 & -0.0455 & -0.4804 & -0.0059 & -0.0062 & -0.0685 & \\
\hline
\end{tabular}

The correlation matrix in table 4 produced statistical evidence that firm leverage is significantly and positively correlated with size and tangibility at the $1 \%$ level with correlation coefficient of $41.29 \%$ and $46.93 \%$ 
respectively. This implies that large companies and companies with higher level of tangible assets tend to use more leverage. Similarly, leverage of a firm has significant negative correlation with profitability and earning volatility at $1 \%$ level with correlation coefficient of $-30.76 \%$ and $-31.16 \%$ respectively. This indicates that profitable companies and companies with high business risk are less likely to use leverage. Even though, the correlation matrix produced negative relationship between growths and leverage of a firm, the relations are not statistically significant.

Moreover, the result of the correlation matrix in table 4 indicates that non-debt tax shields and age variables have statistical significant positive correlation with leverage at $1 \%$ of level with correlation coefficient of $47.26 \%$ and $31.18 \%$ respectively. However, dividend payout ratio variable indicate strong negative correlation with firm's leverage at a correlation coefficient of $-32.45 \%$.

In order to shade more light on the relationship and implication of the explanatory variables on leverage of the firm the following regression analysis was conducted.

Table 5. Regression result of leverage and explanatory variables

\begin{tabular}{lllll}
\hline LEV & Coefficient & Std. Err. & $\mathrm{t}$ & $\mathrm{P}>|\mathrm{t}|$ \\
\hline PROF & -0.1462 & 0.0482 & -3.03 & $0.002^{*}$ \\
SIZE & 0.0185 & 0.008 & 2.32 & $0.021^{* *}$ \\
TANG & 0.0865 & 0.051 & 1.69 & $0.090^{* * *}$ \\
NDTS & 1.0837 & 0.24 & 4.52 & $0.000^{*}$ \\
GROW & -0.0223 & 0.0184 & -1.21 & 0.225 \\
AGE & 0.0016 & 0.0008 & 1.94 & $0.053^{* * *}$ \\
LIQU & 0.0074 & 0.002 & 3.6 & $0.000^{*}$ \\
DPR & -0.0602 & 0.0186 & -3.23 & $0.001^{*}$ \\
EV & -112.1539 & 42.0931 & -2.66 & $0.008^{*}$ \\
Cons. & -0.2765 & 0.1526 & -1.81 & 0.07 \\
Wald chi2 $(9)=124.93$ & & & \\
Prob $>$ chi2 $=0.0000$ & & & \\
$1 \%$ level, ** denotes Significance at $5 \%$ level and *** denotes Significance at $10 \%$ level.
\end{tabular}

From Table 5 of regression result, the regression equation can be developed as follows:

$$
\begin{gathered}
L E V=-0.28-0.15 P R O F+0.02 \text { SIZE }+0.09 \text { TANG }+1.08 \mathrm{NDTS}-0.02 \mathrm{GROW}+ \\
0.002 A G E+0.007 \mathrm{LIQU}-0.06 \mathrm{DPR}-112.15 E V+u_{i}+\varepsilon_{i t}
\end{gathered}
$$

As can be observe from regression results on table 5, with the exception of growth variable other explanatory variables were found to be statistically significant in affecting leverage of large taxpayer share companies in Ethiopia, holding other things constant. The outcome also shows that a significant positive coefficient of size variable for the sample of firms in the study. This result proves that giant share companies prefer to finance their project more from debt related securities than equity related securities. Conversely small sized share companies direct their finance structure towards equity. Similarly, there is valid positive relationship between dependent variable leverage and tangible asset of the company. The positive coefficient of tangibility variable demonstrates that firms with more tangible assets have a greater ability to secure debt and collateral value is found to be the factor affecting the leverage of large taxpayer share companies in Ethiopia.

Beta coefficient associated with non-debts tax shields reveals that a significant positive relation with firm leverage. One of the possible explanations of the sign of this result could be that tax deduction for depreciation is not substitution for the tax advantage of debt financing. Accordingly, share companies with a large non-debt tax shield are likely to be more leveraged. The regression result also shows a significant positive association between leverage ratio and age of the firm. This gives an idea about the experienced share companies include more debt than equity in their capital structure. Conversely, starter organizations' capital structure comprises more equity than debt capital.

Another contributing factor that significantly and positively influences capital structure of large taxpayer share companies are their liquidity position. Considering this fact, it is likely that the more the large taxpayer share companies in Ethiopia able to meet short term obligation the more they use long term debt securities in their capital structure. Conversely, earnings volatility or business risk of large taxpayer share companies negatively 
relate with leverage of a firm. This demonstrates that large taxpayer share companies with high degree of volatility in their operating income maintain low level of leverage in their capital structure.

Finally, the regression results indicate that tangibility is more important determinants of leverage in Ethiopian large taxpayer share companies. Creditors give priority to candidates with more tangible assets and specifically possess sufficient collateralized value in their asset structure when advancing loan to clients. This type of credit policy is common in countries with weak creditor protection than in countries with strong creditor protection, indicating that creditors would request more tangibility of asset in the asset structure or collateral for loans. This is also probably attributable to high risk-averse creditors wishing a strong guarantee on their loan in situation when proposed projects or investments fail to provide the firm with the expected return.

\subsection{Hypothesis Testing}

As the above section presents the brief discussion of the regression results, this section of the study gives a detail hypothesis testing by pointing which of the capital structure theories are applicable to Ethiopian context after matching the regression results with the expected sign of relationship between leverage and its determinants.

Hypothesis testing conducted based on the relationship of dependent variable leverage and independent variables with reference to previous empirical studies and the three capital structure theories that is trade-off theory, pecking order theory and agency cost theory.

Table 6. Predicted, theoretical and actual sign of the coefficient of independent variables

\begin{tabular}{|c|c|c|c|c|c|c|}
\hline \multirow[t]{2}{*}{$\begin{array}{l}\text { Independent } \\
\text { Variables }\end{array}$} & \multirow[t]{2}{*}{ Definition } & \multirow[t]{2}{*}{$\begin{array}{c}\text { Predicted } \\
\text { Sign }\end{array}$} & \multicolumn{3}{|c|}{$\begin{array}{l}\text { Theoretical signs of } \\
\text { independent variables } \\
\text { based on capital } \\
\text { structure theories }\end{array}$} & \multirow[t]{2}{*}{ Actual Sign } \\
\hline & & & TOT & POT & $\mathrm{ACT}$ & \\
\hline PROF & Ratio of operating income to total asset & - & + & - & $?$ & - \\
\hline SIZE & Natural logarithm of total assets & + & + & + & + & + \\
\hline TANG & Ratio of fixed assets to total assets & + & + & + & + & + \\
\hline NDTS & Ratio of depreciation to total assets & - & - & $?$ & $?$ & + \\
\hline GROW & Percentage increase in total assets & - & - & + & - & - \\
\hline AGE & Number of years stay in the business & - & + & - & $?$ & + \\
\hline LIQU & Ratio of current assets to current liabilities & + & $?$ & $?$ & $?$ & + \\
\hline DPR & Ratio of cash dividend to total net income & + & $?$ & + & - & - \\
\hline EV & $\begin{array}{c}1 / \text { Square root of the standard deviation of } \\
\text { operating income }\end{array}$ & - & - & - & $?$ & - \\
\hline
\end{tabular}

Notes: "TOT" indicate Trade-Off Theory, "POT" signify Pecking-Order Theory and "ACT" denotes Agency Cost Theory. "+" indicate that a positive relationship between the independent variable and leverage. "-“ indicate that a negative relationship between the independent variable and leverage. "?" indicate that the available literature does not indicate a clear outcome for the relationship.

Table 6 gives a summary of formulated hypothesis, theoretical framework concerning independent variables and the actual sign of independent variables from the regression result for large taxpayer share companies in Ethiopia.

Bearing in mind the formulated hypothesis in the third section of this paper, the first hypothesis was postulated in order to assess the relationship between leverage of a firm and profitability based on pecking-order theory, on the grounds that there is significant negative relationship between profitability and leverage. In conformity with the hypothesis the actual sign of the coefficient of profitability variable are negatively and strongly relate with leverage at $1 \%$ level of significance. This fact provide empirical support for the first hypothesis and provide evidence that, citrus paribus the more the share companies generate profit the less they uses leverage in financing their fund requirement. They prefer internal financing to external debt securities and vice versa. This finding is in line with with the results observed by Titman and Wessels (1988); Rajan and Zingales (1995) and Bevan and 
Danbolt (2002) in developed countries, Booth et al. (2001); Pandy (2001); Wiwattanakantang (1999); Chen (2004) in developing countries.

The second hypothesis formulated related to financing decision was there is significant positive relationship between leverage and size of a company based on the combined prediction of trade-off, pecking order and agency cost theory. In agreement to the formulated hypothesis, the regression result exhibits statistical evidence of a positive relationship between size and leverage of large taxpayer share companies in Ethiopia at $5 \%$ level of significance. Thus, hypothesis two is accepted. This finding suggests that large firms have the ability to use more debt on their capital structure than equity related securities; perhaps they can have a greater bargaining power towards creditors. The finding of Wiwattanakantang (1999); Al-Sakran (2001); Booth, et al. (2001); Pandy (2001); Huang and Song (2002) shows a significant positive correlation between size and leverage ratio of a firm in developing countries.

A significant positive relationship between tangibility and leverage of a firm was observed in the regression result for the tangibility variable. It gives a balanced evidence for the third hypothesis and three arenas of capital structure theories since all the theories expect a positive relation between tangibility and leverage. In consistency with this study, the findings of Wiwattanakantang (1999) in Thailand; the study of Um (2001) in South Korea; the work of Attaullah and Sufiullah (2007) study in Pakistan; the examination of Dilek, Ozlem and Ayca (2009) for Turkish firms form developing countries and investigation of Rajan and Zingales (1995) and Titman and Wessels (1988) in developed countries reveals a positive relationship between tangibility and leverage.

The fourth hypothesis was formulated in order to evaluate the relationship between non-debts tax shields and leverage of a firm on the basis of trade-off theory on the ground that there is significant negative relationship between non-debts tax shields and leverage. Beta coefficient associated with non-debts tax shields shows a significant positive relation with firms leverage. This leads to reject the fourth hypothesis. Therefore, share companies with a large non-debt tax shield are likely to be more leveraged. The positive impact of non-debt tax shield on leverage is in support of the findings of some empirical studies such as Bradly et al. (1984), and Rafiu and Akinlolu (2008) from Nigeria firms.

Hypothesis five predicted that significant negative relationship exists between growth variable and leverage. In agreement with the hypothesis, the regression result exhibit inverse relationship between growth and leverage of a firm as suggested by trade-off and agency cost theory. Even though, the beta coefficient indicates the predicted theoretical relation between growth and leverage ratio, this is statistically insignificant. This can be interpreted as growth variable does not enlighten the variation in the leverage ratio and is found to be insignificant factor to decide the capital structure of large taxpayer share companies in Ethiopia.

Hypothesis six was postulated to estimate the relationship between leverage and age on the basis of pecking order theory. The regression result in this study rejects the hypothesis by providing empirical evidence that age variable significantly and negatively impact on leverage and this outcome confirms with trade-off theory and the findings of Esperanca, Gama and Gulamhussen (2003). This gives a meaning that at the initial stage of operating years; share companies raise more money from debt related sources. While, as companies stay in business and get more experience they redirect their financing gears towards equity schemes.

Hypothesis seven was stated to assess the relationship between liquidity and financing decision of a company. A positive beta coefficient of liquidity variable on the regression result confirms the seventh hypotheses, that firms with high liquidity position are more levered. The beta coefficient is statistically significant at $1 \%$ level. This implies that the more the share companies are able to meet short term obligation the more they use long term debt securities in their capital structure. This finding provides empirical support for the prediction of Williamson (1988); Morellec (2001); Bogdana (2009), and Valeriy (2007) for U.S. public companies.

Hypothesis eight predicted that a significant negative relationship exists between dividend payout ratio and leverage in line with the idea of pecking order theory. On the contrary to the hypothesis, the regression result provides empirical evidence that there is significant negative relationship between growth and leverage as postulated by agency cost theory. This indicates that instead of distributing high dividend, share companies retain earnings to meet their financial need. The same result was obtained by Bhaduri (2002) from the Indian corporate structure.

The last hypothesis was formulated in order to assess the relationship between earnings volatility and leverage of a firm based on the communal prediction of trade-off, pecking order and agency cost theory on the grounds that there is significant negative relationship between earnings volatility and firms leverage. In conformity with the extant theories and hypothesis, the regression result reveals that there is significant negative relation between earnings volatility and leverage of a firm at $1 \%$ level of significance. This entails that large taxpayer share 
companies with high degree of volatility in their operating income maintain low level of leverage in their capital structure. Similar findings were obtained by Bradly et al. (1984); Titman and Wessel (1988) and Attaullah and Sufiullah (2007).

\section{Conclusion}

The regression result reveal that except growth variable other explanatory variables were statistically significant in affecting leverage of large taxpayer share companies in Ethiopia, holding other things constant. The outcome also shows that a significant positive relationship between size, tangibility, non-debts tax shield variables and leverage ratio of firms. Likewise, age and liquidity position of the company found positively correlated with dependent variable leverage. On the other hand, profitability, dividend payout ratio and earnings volatility of firms is inversely and significantly related with leverage of a firm.

A cautious comparison of regression result with the expected sign of capital structure theories between leverage and explanatory variables, provides evidence that trade-off, pecking order and agency cost theories contribute their own parts in explaining the determinants of capital structure. However, considering the above facts it is possible to conclude that large taxpayer share companies in Ethiopia inclined more to an agency cost theory in financing their investment.

This paper examines only firms-specific factors that influence companies leverage ratio. The effect of another group of macroeconomic factors like inflation, stock market value, and real GDP growth rate (Booth et al. 2001) could have a role in determining the capital structure choice. Even though, analyzing and understanding of these factors are important and interesting, they did not give due consideration is this paper as a result of they are beyond the scope of this study.

\section{References}

Al-Sakran, S. (2001). Leverage determinants in the absence of corporate tax system: The case of non-financial publicly traded corporations in Saudi Arabia. Managerial Finance, 27, 58-86. http://dx.doi.org/10.1108/03074350110767583

Antoniou, A., Guney, Y., \& Paudyal, K. (2002). Determinants of corporate capital structure: Evidence form european countries. Working Paper, University Of Durham.

Attaullah, S., \& Sufiullah, K. (2007). Determinants of capital structure: Evidence from Pakistani panel data. International Review of Business Research Papers, 3, 265-282.

Bancel, F., \& Mitto, U. (2004). Cross-country determinants of capital structure choice: A survey of European firms. Financial Management, 33(4), 103-132.

Berger, A., \& Udell, G. (1998). The economics of small business finance: The role of private equity and debt markets in the financial growth cycle. Journal of Banking and Finance, 22, 613-673. http://dx.doi.org/10.1016/S0378-4266(98)00038-7

Bevan, A., \& Danbolt, J. (2002). Capital structure and its determinants in the UK-A decomposition analysis. Applied Financial Economics, 12, 159-170. http://dx.doi.org/10.1080/09603100110090073

Bhaduri, S. (2002). Determinants of corporate borrowing: Some evidence from the Indian corporate structure. Journal of Economics and Finance, 26(2), 200-216. http://dx.doi.org/10.1007/BF02755986

Bogdana, G. (2009). Corporate capital structure choice: Does managers' gender matter. Master Thesis, Kyiv School of Economics.

Booth, L. (2001). Capital structure in developing countries. Journal of Finance, 56, 97-129. http://dx.doi.org/10.1111/0022-1082.00320

Bradly. (1984). On the existence of an optimal capital structure: Theory and evidence. Journal of Finance, 39(3), 857-978. http://dx.doi.org/10.1111/j.1540-6261.1984.tb03680.x

Chen, J. (2004). Determinants of capital structure of Chinese-listed companies. Journal of Business Research, 57 , 1341-1351. http://dx.doi.org/10.1016/S0148-2963(03)00070-5

Chung, K. (1993). Asset characteristics and corporate debt policy: An empirical test. Journal of Business Finance and Accounting, 20, 83-98. http://dx.doi.org/10.1111/j.1468-5957.1993.tb00251.x

Commercial Code of the Empire of Ethiopia. (1960). Proclamation No. 166.

DeAngelo, H., \& Masulis, R. (1980). Optimal capital structure under corporate and personal taxation. Journal of Financial Economics, 8(1), 3-29. http://dx.doi.org/10.1016/0304-405X(80)90019-7 
Dilek, T., Ozlem, T., \& Ayca, T. (2009). Determinants of capital structure for Turkish firms: A panel data analysis. International Research Journal of Finance and Economics, 29, 180-187.

Esperanca, J. P., Gama, A. P. M., \& Gulamhussen, M. A. (2003). Corporate debt policy of small firms: An empirical (Re) examination. Journal of Small Business and Enterprise Development, 10, 62-80. http://dx.doi.org/10.1108/14626000310461213

Fakher, B., Kenbata, B., \& Lynn, H. (2005). Determinants of capital structure: Evidence from Libya. Research Paper Serious, 8.

Ferri, M., \& Jones, W. (1979). Determinants of financial structure: A new methodological approach. The Journal of Finance, 34(3), 631-644. http://dx.doi.org/10.1111/j.1540-6261.1979.tb02130.x

Fitzoroy, D. (2000). Corporate finance capital structuring. Chicago: Fitzroy Dearborn Publishers.

Francisco, S. (2001). On capital structure in the small and medium enterprise: The Spanish case. Universidad Cardenal Herrera - CEU.

Frank, M., \& Goyal, V. (2003). Testing the pecking order theory of capital structure. Journal of Financial Economics, 67(2), 217. http://dx.doi.org/10.1016/S0304-405X(02)00252-0

Hall, G., Hutchinson, P., \& Michaelas, N. (2004). Determinants of the capital structure of European SMEs. Journal of Business Finance and Accounting, 31, 711-728. http://dx.doi.org/10.1111/j.0306-686X.2004.00554.x

Hausman, J. (1978). Specification tests in econometrics. Econometrica, 46, 297-355. http://dx.doi.org/10.2307/1913827

Huang, G., \& Song, F. (2002). The determinants of capital structure: Evidence from China. Working Paper, University of Hong Kong.

Huang, G., \& Song, F. (2006). The determinants of capital structure: Evidence from China. China Economic Review, 17(1), 14-36. http://dx.doi.org/10.1016/j.chieco.2005.02.007

Huang, H., \& Vu Thi, T. (2002). The determinants of capital structure in shipping industry: Case studies of brostrom and concordia $A B$. Master Thesis, University of Goteborg.

Jensen, M., \& Meckling, W. (1976). Theory of the firm: Managerial behavior, agency costs, and capital structure. Journal of Financial Economics, 3(4), 305-360. http://dx.doi.org/10.1016/0304-405X(76)90026-X

Keshar, J. (2004). Determinants of capital structure: A case study of listed companies of nepal. The Journal of Nepalese Business Studies, 1(1).

Kester, V. (1986). Capital and ownership structure: A comparison of United States and Japanese manufacturing corporation. Financial Management, 15, 5-16. http://dx.doi.org/10.2307/3665273

Kim, W., \& Sorensen, E. (1986). Evidence of the impact of the agency cost of debt on corporate debt policy. Journal of Financial and Quantitative Analysis, 21, 131-144. http://dx.doi.org/10.2307/2330733

Kumer, R., \& Reddy, V. (1998). Econometric analysis of the capital structure determinants. Working Paper Series 333. Indian Institute of Management Calcutta.

Lewis-Beck, M. (1993). Applied regression: An introduction in regression analysis. International Handbook of Quantitative Applications in the Social Sciences, 1, 68.

Maksimovic, V., \& Phillips, G. (2001). The market for corporate asset: Who engages in mergers and asset sales and are there efficiency gains? Journal of Finance, 56, 2019-2065. http://dx.doi.org/10.1111/0022-1082.00398

Modigliani, F., \& Miller, M. (1958). The cost of capital, corporate finance and the theory of investment. American Economic Review, 48, 261.

Modigliani, F., \& Miller, M. (1963). Corporate income taxes and the cost of capital: A correction. American Economic Review, 53, 433-443.

Mohammed, A. (2007). Determinants of capital structure of banks in Ghana: As empirical approach. Baltic Journal of Management, 2(1), 67-79. http://dx.doi.org/10.1108/17465260710720255

Morellec, E. (2001). Asset liquidity, capital structure and secured debt. Journal of Financial Economics, 61, 173-206. http://dx.doi.org/10.1016/S0304-405X(01)00059-9

Myers, S. (1977). The determinants of corporate borrowing. Journal of Financial Economics, 5, 147-175. 
http://dx.doi.org/10.1016/0304-405X(77)90015-0

Myers, S. (1984). The capital structure puzzle. Journal of Finance, 39(3), 575-592. http://dx.doi.org/10.2307/2327916

Myers, S., \& Majluf, N. (1984). Corporate financing and investment decisions when firms have information investors do not have. Journal of Financial Economics, 13, 187-222. http://dx.doi.org/10.1016/0304-405X(84)90023-0

Myroshnichenko, O. (2004). Determinates of capital structure of Ukrainian corporation. Master thesis, National University "Kyiv-Mohyla Academy".

Ozkan, A. (2001). Determinants of capital structure and adjustment to long run target: Evidence from UK company panel data. Journal of Business Finance and Accounting, 28(2), 175-198. http://dx.doi.org/10.1111/1468-5957.00370

Pandy, M. (2001). Capital structure and the firm characteristics: Evidence from an emerging market. Working Paper, Indian Institute of Management Ahmadabad.

Petersen, M., \& Rajan, R. (1994). The benefits of lending relationship: Evidence from small business data. The Journal of Finance, 49(1), 3-37. http://dx.doi.org/10.1111/j.1540-6261.1994.tb04418.x

Philippe, G. (2003). The capital structure of Swiss companies: As empirical analysis using dynamic panel data. Retrieved March 10, 2011, from http://www.fmpm.org/docs/papers_6/papers

Rafiu, O., \& Akinlolu, A. (2008). The determinants of capital structure of large non-financial firms in Nigeria. The International Journal of Business and Finance Research, 2(2), 75-84.

Rajan, R., \& Zingales, L. (1995). What do we know about capital structure? Some evidence from international data. Journal of Finance, 50, 1421-1460. http://dx.doi.org/10.1111/j.1540-6261.1995.tb05184.x

Scott, J. (1977). Bankruptcy, secured debt, and optimal capital structure. Journal of Finance, 33(1), 1-19. http://dx.doi.org/10.1111/j.1540-6261.1977.tb03237.x

Shleifer, A., \& Vishny, R. (1992). Liquidity values and debt capacity: A market equilibrium approach. Journal of Finance, 47, 1343-1366. http://dx.doi.org/10.1111/j.1540-6261.1992.tb04661.x

Stulz, R. (1990). Managerial discretion and optimal financing policies. Journal of Financial Economics, 26, 327. http://dx.doi.org/10.1016/0304-405X(90)90011-N

Titman, S., \& Wessels, R. (1988). The determinants of capital structure choice. Journal of Finance, 43(1), 1-19. http://dx.doi.org/10.1111/j.1540-6261.1988.tb02585.x

Tongying, L., \& Junyong, Z. (2005). Board characteristics and capital structure: An empirical study on China's private listed companies. Journal of Modern Accounting and Auditing, 1(7), 31-40.

Um, T. (2001). Determinants of capital structure and prediction of bankruptcy in Korea. Unpublished PHD thesis, Cornell University.

Valeriy, S. (2007). Asset liquidity and capital structure. University of Wisconsin-Milwaukee. Retrieved on March 10, 2011, from http://pantherfile.uwm.edu/sibilkov/www/liquidity.pdf

Wald, J. (1999). How firm characteristics affect capital structure: An international comparison. The Journal of Financial Research, 22(2), 161-187.

Williamson, O. (1988). Corporate finance and corporate governance. Journal of Finance, 43, 567-591. http://dx.doi.org/10.1111/j.1540-6261.1988.tb04592.x

Wiwattanakantang, Y. (1999). An empirical study on the determinants of the capital structure of Thai firms. Pacific-Basin Finance Journal, 7, 371-403. http://dx.doi.org/10.1016/S0927-538X(99)00007-4

\section{Copyrights}

Copyright for this article is retained by the author(s), with first publication rights granted to the journal.

This is an open-access article distributed under the terms and conditions of the Creative Commons Attribution license (http://creativecommons.org/licenses/by/3.0/). 